\title{
WHISTLEBLOWING BERDASARKAN INTENSITAS MORAL, KOMITMEN PROFESIONAL, DAN TINGKAT KESERIUSAN KECURANGAN
}

\author{
Ratna Arizka Primasari ${ }^{1}$, Fidiana Fidiana ${ }^{2}$ \\ ${ }^{1,2}$ Program Studi Akuntansi, Sekolah Tinggi Ilmu Ekonomi Indonesia Surabaya \\ fidiana@stiesia.ac.id
}

\begin{abstract}
This research aimed to examine empirically the effect of morale intensity, professional commitment, and fraud seriousness rate on the intention of whistleblowing of Regional Revenue Agency of East Java Province, city of Surabaya. Moreover, the data collection technique used purposive sampling. In line with, there were 112 employees as sample. However, only 103 employees who returmed the questionnaires, Furthermore, the data analysis technique used multiple linear regression with IBM SPSS 16. The research result concluded morale intensity, professional commitment, and fraud seriousness rate had positive effect on the intention of whistleblowing. This fact could be seen from the morale intensity which used as behavior control in having intention of whistleblowing. In addition, professional commitment or high dedication on its profession based on the ethics standard could be used in order to avoid the fraud. In other words, the higher the fraud seriousness rate, the more intensity of whistleblowing would occur.
\end{abstract}

Keywords: Fraud seriousness rate, Moral intensity, Professional commitment, Whistleblowing.

\section{Abstrak}

Kajian ini bertujuan untuk membuktikan secara empiris pengaruh intensitas moral, komitmen profesional, dan tingkat keseriusan kecurangan terhadap niat untuk whistleblowing. Kajian dilakukan pada Badan Pendapatan Daerah Jawa Timur Kota Surabaya. Teknik pengambilan sampel dengan metode purposive sampling menghasilkan 112 sampel, namun hanya 103 sampel kuesioner yang lengkap dan layak diujikan. Analisis data menggunakan analisis regresi linier berganda. Berdasarkan hasil pengolahan data dengan IBM SPSS versi 16 menunjukkan bahwa intensitas moral, komitmen profesional, dan tingkat keseriusan kecurangan berpengaruh positif terhadap niat untuk whistleblowing. Hal ini menunjukkan bahwa intensitas moral dapat menjadi kontrol perilaku dalam mengambil keputusan untuk whistleblowing. Selain itu, komitmen profesional atau rasa dedikasi yang tinggi terhadap profesinya seiring dengan standar etika dapat mengambil sikap untuk menghindari adanya kecurangan yang terjadi dan seriusnya tindakan kecurangan yang sangat berpotensi merugikan lembaga akan meningkatkan niat untuk melakukan whistleblowing. menunjukkan bahwa besar dan seriusnya tindakan kecurangan yang sangat berpotensi merugikan lembaga dan bahkan pada negara, maka tentunya hal ini yang semakin mendorong setiap karyawan untuk melakukan tindakan whistleblowing karena baginya, perusahaan akan terkena dampak berupa kerugian yang bersifat besar dan serius

Katakunci: Intensitas moral, Keseriusan kecuranngan, Komitmen profesional, Whistleblowing.

Cronicle of Article: Received (April 2020); Revised (May 2020); and Published (June 2020).

(C2019 Jurnal Kajian Akuntansi Lembaga Penelitian Universitas Swadaya Gunung Jati.

Profile and corresponding author: Ratna Arizka Primasari and Fidiana are from Accounting Study Program, Sekolah Tinggi Ilmu Ekonomi Indonesia Surabaya.

Corresponding Author: fidiana@stiesia.ac.id.

How to cite this article: Primasari, R. A., \& Fidiana, F. (2020). Whistleblowing berdasarkan Intensitas Moral, Komitmen Profesional, dan Tingkat Keseriusan Kecurangan. Jurnal Kajian Akuntansi, 4 (1), 63-77. 


\section{PENDAHULUAN}

Perusahaan tidak terlepas dari ancaman kecurangan (fraud), baik berupa kecurangan aset (asset misappropriation), pernyataan palsu atau salah pernyataan (fraudulent statement), dan korupsi (ACFE, 2016). Penyalahgunaan ini melibatkan berbagai pihak internal dan pihak eksternal dengan memiliki motif yang sama yaitu berupaya dalam memperkaya diri sendiri maupun sekelompok dan merugikan pihak lain dengan melakukan hal yang dianggap illegal dalam hukum (Mohd Noor \& Mansor, 2019). Berdasarkan Fraud Triangle Theory, kecurangan terjadi secara umum disebabkan oleh tekanan, kesempatan, dan pembenaran (Cressey, 1986).

Whistleblowing merupakan pengungkapan tindakan pelanggaran atau perbuatan yang melawan hukum, tidak bermoral atau perbuatan lain yang dapat merugikan organisasi atau pemangku kepentingan, yang dilakukan oleh karyawan atau pimpinan organisasi kepada pimpinan organisasi atau lembaga lain yang dapat mengambil tindakan atas pelanggaran tersebut (KKNG, 2008). Whistleblowing dibedakan menjadi dua jenis yaitu whistleblowing internal dan whistleblowing eksternal. Whistleblowing internal merupakan pelaporan oleh suatu individu atau kelompok atas tindakan kecurangan yang dilakukan pihak terlapor kepada pimpinan organisasi. Sedangkan, whistleblowing eksternal merupakan tindakan suatu individu atau kelompok yang mengetahui adanya kecurangan oleh pihak lain dan mengungkapkan kepada masyarakat, karena ingin mencegah kerugian bagi masyarakat (Alfian, Subhan, \& Rahayu, 2018).

Kecurangan juga mengancam organisasi sektor publik. Padahal organisasi ini berorientasi pada kepentingan publik yang diharapkan dan dipercaya oleh masyarakat untuk mengelola pemerintahan dengan baik sehingga mampu memberikan pelayanan yang optimal. Kenyataannya, kecurangan juga sering terjadi pada entitas ini namun terkadang sulit untuk terdeteksi.

Indikasi penyelewengan pada aktivitas layanan publik dalam bentuk korupsi dan turunannya seperti suap, gratifikasi, penyalahgunaan wewenang hingga pemerasan memang banyak terjadi di pemerintahan (Hartono \& Cahaya, 2017; Saputra, Utami, \& Kristianti, 2018). Hal ini dapat dipahami bahwa di pemerintahan identik dengan birokrasi yang rumit sehingga memungkinkan terjadinya penyimpangan. Beberapa indikasi kasus penyelewengan terungkap berkat adanya pelapor (whistleblower) seperti pada kasus BLBI (bantuan likuiditas Bank Indonesia), proyek E-KTP, Kasus Hambalang-proyek P3SON (pembangunan Pusat Pendidikan, Pelatihan, dan Sarana Olahraga Nasional). Meluasnya kecurangan di entitas sektor publik mendorong diterapkannya sistem pelaporan kecurangan yang sering disebut sebagai whistleblowing system (Valentine \& Godkin, 2019). Saat ini, setiap pemerintah daerah telah mengembangkan sistem pengaduan (whistleblowing) berbasis aplikasi yang biasa dikenal dengan WBS (whistleblower system). Sistem aduan ini diharapkan dapat mengungkap adanya indikasi penyelewengan di lingkungan pemerintahan tetapi tetap melindungi hakhak pelapor termasuk keamanan diri pelapor.

Ketersediaan WBS tidak akan efektif jika tidak ada kemauan dan partisipasi aparatur sipil negara atau masyarakat yang mengetahui adanya indikasi penyelewengan untuk melapor. Peran whistleblower sangat penting untuk mengungkap penyimpangan dan perilaku non-etis di entitas publik sehingga pemerintah dapat meningkatkan akuntabilitas publik dan lebih transparan (Jeon, 2017).

Tidak mudah bagi individu untuk memutuskan menjadi whistleblower. Individu akan berhadapan dengan dilema 
apakah akan meniup peluit atau membiarkan saja kecurangan terjadi (Iskandar \& Saragih, 2018).

Beberapa kajian mengemukakan ketidaksediaan menjadi whistleblower karena enggan dianggap penghianat, tidak etis, tidak loyal, tidak setia terhadap organisasi dan rekan kerja (Farooqi, Abid, \& Ahmed, 2017). Pelapor juga seringkali menerima ancaman kehidupan pribadi dan keluarganya. Selain itu, pelaku tindak kecurangan seringkali lolos hukum. Alasan-alasan tersebut akan mendistorsi niat whistleblowing. Praktis, setiap individu akan merespon secara berbeda saat mengetahui adanya indikasi tindak kecurangan atau penyelewengan.

Individu berhadapan dengan persepsi, faktor situasi, dan faktor dalam diri objek atau target yang membentuk unsur-unsur penilaian baik atau buruknya suatu perilaku (Robbins \& Judge, 2017).

Saat individu menganggap kecurangan itu merupakan tindakan ilegal dan buruk, maka keinginan melakukan whistleblowing untuk mencegah kecurangan akan muncul sehingga akan melakukan tindakan whistleblowing. Penilaian setiap individu akan berbeda sesuai intensitas moral yang dimiliki masing-masing individu. Penelitian sebelumnya yang dilakukan oleh (Hariyani \& Putra, 2018; Setiawati \& Sari, 2016; Zanaria, 2016) menyatakan bahwa intensitas moral memiliki pengaruh positif terhadap niat untuk whistleblowing. Hal tersebut bisa disimpulkan bahwa semakin tinggi intensitas moral yang dimiliki individu niat untuk whistleblowing akan meningkat pula.

Whistleblower meminimalisir kecurangan dengan melakukan whistleblowing bertujuan menjaga keberlangsungan organisasi tempat ia bekerja. Sehingga, tindakan yang dilakukan berdasarkan standar etika dan profesional yang mencakup tanggungjawabnya dengan berdedikasi terhadap pekerjaan yang diukur dari komitmen profesional dalam kecakapan dan pengetahuan yang dimilikinya (Setiawati \& Sari, 2016). Penelitian sebelumnya yang dilakukan oleh (Hariyani \& Putra, 2018; Nur \& Hamid, 2018; Zanaria, 2016) menyatakan bahwa komitmen profesional memiliki pengaruh positif terhadap niat untuk whistleblowing. Sehingga, semakin tinggi komitmen profesional individu, maka niat untuk whistleblowing akan meningkat pula. Penelitian sebelumnya yang dilakukan oleh (Lestari \& Yaya, 2017; F. C. P. Mulfag \& Serly, 2019; Wakerkwa et al., 2018) menyatakan bahwa komitmen profesional memiliki pengaruh positif terhadap niat untuk whistleblowing.

Kajian tentang whistleblowing telah banyak dilakukan termasuk pada sektor privat dan sektor publik. Kajian ini berbeda dengan kajian whistleblowing sebelumnya dengan menambahkan tingkat keseriusan kecurangan. Terjadinya kecurangan yang dapat memberikan dampak berupa kerugian kecil hingga kerugian besar yang mencakup seluruh lingkungan organisasi. Dampak yang diberikan kepada organisasi diacu oleh keseriusan kecurangan yang telah dilakukan oleh pihak terkait. Individu akan termotivasi untuk melakukan whistleblowing guna menghentikan atau mencegah kerugian yang lebih besar jika kecurangan yang terjadi memiliki dampak yang sangat besar dan memungkinkan terjadinya kerugian. Kajian tingkat keseriusan kecurangan sebelumnya banyak dikaitkan dengan pengendalian internal, kajian ini merelasikan dengan niat untuk whistleblowing.

Kajian ini dilakukan pada Badan Pendapatan Daerah Jawa Timur Kota Surabaya, yang merupakan salah satu unit penting pengelola keuangan di Kota Surabaya. Sebagai satuan kerja yang kegiatan operasionalnya berkaitan dengan uang, unit ini sangat rawan terjadi tindak kecurangan. Kajian whistleblowing dengan konsep TPB (theory of planned behavior), menurut penelusuran penulis jarang diaplikasikan pada perilaku aparatur sipil 
negara di lingkup perangkat daerah. Padahal, tidak sedikit kasus kecurangan justru terjadi di unit perangkat daerah.

Kajian ini bertujuan untuk menguji empiris apakah intensitas moral, komitmen profesional dan tingkat keseriusan kecurangan berpengaruh terhadap niat untuk whistleblowing (Ahmad, Yunos, Ahmad, \& Sanusi, 2014; Nisar, Prabhakar, \& Torchia, 2019; Valentine \& Godkin, 2019).

\section{ZKAJIAN PUSTAKA \\ Theory of Planned Behaviour (TPB)}

Theory of Planned Behaviour (TPB) muncul sebagai solusi atas tidak berhasilnya pengaruh sikap (attitude) dalam memperkirakan tindakan atau perilaku aktual (actual behavior) secara langsung (Ajzen, 1991). TPB membuktikan bahwa minat lebih akurat dalam memperkirakan perilaku sesungguhnya serta dapat sebagai jalur yang menghubungkan antara sikap dan perilaku sesungguhnya. TPB memiliki 3 (tiga) konsep yang mendorong kemungkinan terjadinya perilaku individu yaitu individu yaitu sikap terhadap perilaku (attitude towards behaviour), norma subjektif (subjective norm), dan persepsi kontrol perilaku (perceived behavioral control).

Persepsi kontrol perilaku merupakan persepsi yang dimiliki oleh individu atas keyakinan dari kontrol dirinya sendiri (Nur \& Hamid, 2018) dan berhubungan dengan intensitas moral. Individu akan melakukan tindakan atau berperilaku sesuai dengan moral yang melekat pada dirinya terhadap suatu kondisi atau lingkungan. Individu akan menentukan tingkatan baik atau buruknya suatu perilaku yang akan dilakukan sesuai atas persepsi kontrol dirinya sendiri.

Sikap terhadap perilaku merupakan tingkatan seseorang memahami dan menilai baik atau buruknya untuk dilakukan serta dapat menguntungkan atau tidaknya. Dorongan dalam diri untuk terjadinya sebuah perilaku didasari sikap yang bijak dan keyakinan individu terhadap suatu kondisi akan mampu mempengaruhi niat individu untuk whistleblowing (Amrullah \& Kaluge, 2019). Komitmen profesional dapat menggambarkan sikap terhadap perilaku. Salah satu sikap seseorang untuk menunjukkan komitmen profesional yaitu dengan mematuhi aturan dan kode etik tertentu yang ada dalam organisasi untuk menjalankan tugasnya, sehingga saat melihat adanya kecurangan yang melanggar aturan yang ada maka akan berperilaku untuk melakukan tindakan mengungkapkan adanya kecurangan (Brown, Hays, \& Stuebs, 2016; Schultz \& Harutyunyan, 2015; Shawver \& Shawver, 2018).

Ketiga faktor diatas dapat menjadi pengaruh dengan tingkatan yang berbedabeda dalam berbagai perilaku dan situasi, namun penelitian ini hanya menggunakan sikap terhadap perilaku dan persepsi kontrol perilaku karena menurut peneliti faktor ini paling dominan terkait dengan niat untuk whistleblowing.

\section{Prosocial Organizational Behaviour Theory}

Prosocial organizational behaviour theory (teori perilaku prososial) adalah anggota suatu organisasi yang melakukan perilaku dalam organisasinya yang bertujuan untuk meningkatkan kesejahteraan individu, kelompok, atau organisasi tersebut (Brief \& Motowidlo, 1986). Teori ini merupakan salah satu teori yang dapat memperkuat adanya tindakan whistleblowing karena berfungsi untuk memberikan manfaat bagi organisasi atau orang lain serta bermanfaat bagi diri pengungkap itu sendiri sehingga whistleblowing dapat disebut sebagai tingkah laku prososial (Marliza, 2018).

Persepsi bahwa semua jenis pelanggaran yang terjadi merupakan jenis pelanggaran yang relatif serius dan dapat menimbulkan dampak kerugian yang relatif besar bagi dirinya dan organisasi 
sehingga whistleblower akan terdorong untuk melaporkan dugaan pelanggaran kepada pihak internal (Mohd Noor \& Mansor, 2019; Near \& Miceli, 2016). Dari temuan tersebut, maka dapat dihubungkan dengan prosocial organizational behavior theory. tingkat materialitas kecurangan maka akan semakin tinggi konsekuensi yang merugikan atau membahayakan berbagai pihak, sehingga pelanggaran tersebut merupakan salah satu faktor pemicu seseorang untuk berperilaku prososial untuk melakukan whistleblowing (Wakerkwa, Falah, \& Safkaur, 2018).

Intensitas moral berasal dari pemikiran individu seberapa baik dan seberapa buruk dari suatu perilaku yang akan dilakukan (Setiawati \& Sari, 2016). Semakin tinggi intensitas moral seseorang, maka intensi melakukan whistleblowing semakin meningkat. Seseorang yang memiliki intensitas moral yang tinggi akan lebih cenderung untuk melaporkan tindakan pelanggaran yang terjadi dikarenakan mereka memiliki rasa tanggungjawab untuk melaporkannya dan sebaliknya apabila intensitas moral seseorang rendah maka dia tidak memiliki rasa tanggung jawab untuk melaporkan tindakan pelanggaran yang terjadi (Nur \& Hamid, 2018).

Untuk menjadi whistleblower, individu harus memiliki komponen kognitif atau keyakinan (salien belief) bahwa whistleblowing merupakan suatu tindakan yang memiliki manfaat yaitu untuk melindungi organisasi, memberantas korupsi, memunculkan efek jera, menumbuhkan budaya antikorupsi, menghasilkan manfaat pribadi seperti reputasi, reward dan sebagainya (Bagustianto \& Nurkholis, 2015). Disimpulkan bahwa semakin tinggi intensitas moral yang dimiliki, semakin tinggi pula niat untuk melakukan tindakan whistleblowing (Husniati, 2017; Setiawati \& Sari, 2016; Zanaria, 2016).

Individu yang memiliki komitmen profesional yang kuat dengan mematuhi aturan yang ada sebagai standar perilakunya cenderung akan melaporkan tindakan pelanggaran dalam organisasi baik untuk melindungi profesi mereka sendiri atau membasmi pelanggaran demi kepentingan publik (Janitra, 2017; Joneta, 2016; Nur \& Hamid, 2018; Setiawati \& Sari, 2016).

Semakin tinggi komitmen profesional maka semakin tinggi pula mereka cenderung menganggap whistleblowing menjadi hal yang penting serta kemungkinan mereka melakukan whistleblowing pun semakin tinggi. Berkomitmen terhadap profesi berarti memiliki keyakinan bahwa profesi yang dilakukan dapat memberikan hal yang baik bagi diri seseorang (Yulianto, 2015).

Keseriusan kecurangan dapat diartikan sebagai dampak yang ditimbulkan dari adanya suatu pelanggaran baik secara ukuran finansial maupun non finansial (Lestari \& Yaya, 2017).

Persepsi tiap anggota organisasi terhadap tingkat keseriusan kecurangan dapat saja berbeda antara satu dengan yang lainnya. Pembentuk persepsi tingkat keseriusan kecurangan selain berkaitan dengan besaran nilai kecurangan, juga tidakdapat dipisahkan dari jenis kecurangan yang terjadi (Bagustianto \& Nurkholis, 2015).

Disimpulkan bahwa semakin tinggi tingkat keseriusan kecurangan yang dapat mengakibatkan kerugian yang besar maka semakin tinggi niat untuk whistleblowing (Lestari \& Yaya, 2017; Marliza, 2018; Prasetyo et al., 2017).

Model penelitian ditunjukkan pada gambar berikut: 


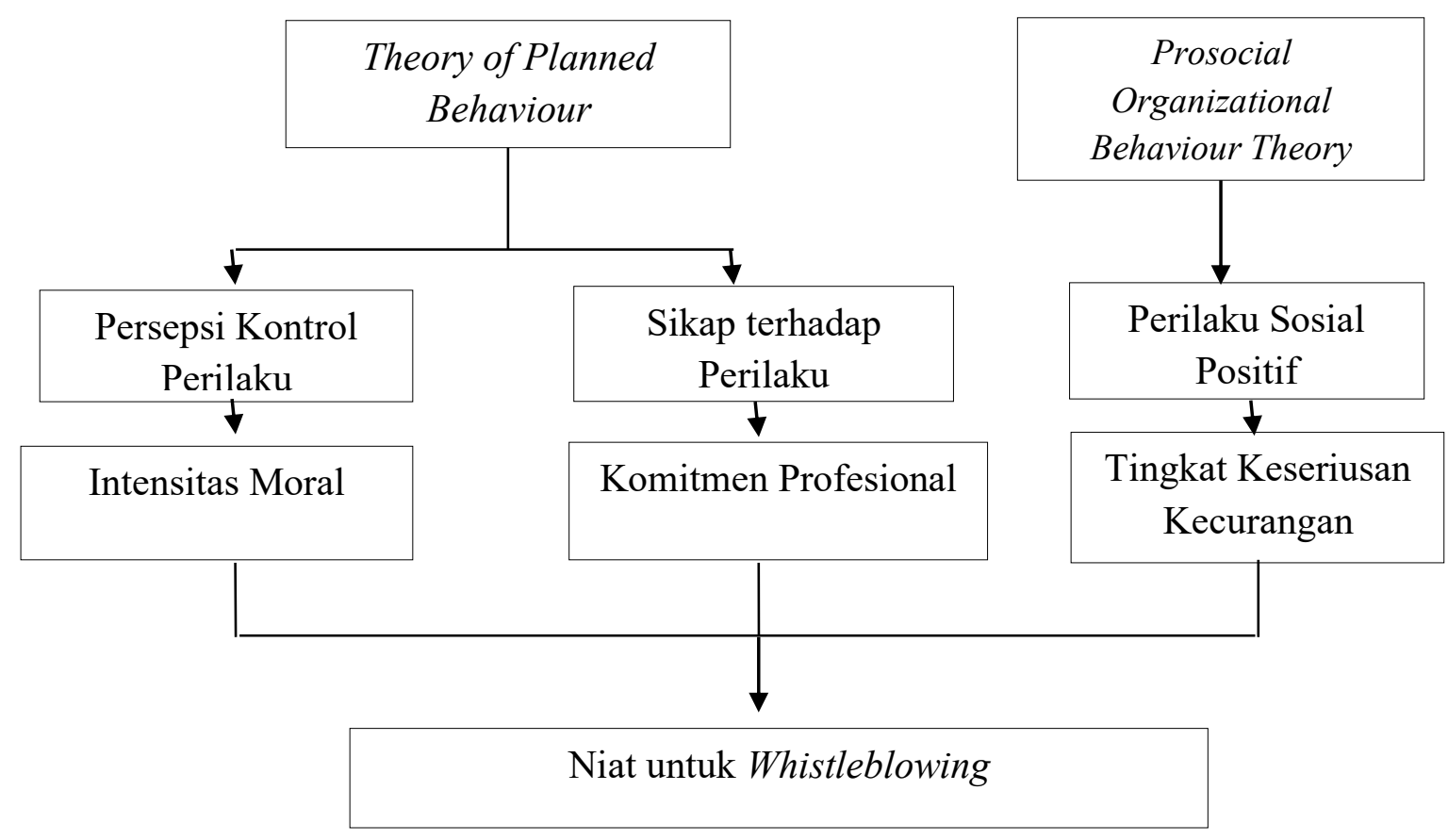

Gambar 1. Rerangka Pemikiran

Sumber: Ringkasan Literatur

\section{METODE PENELITIAN}

Jenis penelitian yang digunakan dalam penilitian ini adalah penelitian kuantitatif. Penelitian kuantitatif merupakan penelitian yang melandaskan filsafat positivisme dengan mengklasifikasikan fenomena atau fakta sebagai hubungan sebab akibat antara dua atau lebih variabel (Sugiyono, 2016). Terkait dengan jenis data, peneliti menggunakan data subyek (self-report data). Data subyek merupakan data penelitian yang berkaitan dengan subyek yang berupa opini, pengalaman, dan tanggapan dari pegawai Badan Pendapatan Daerah Jawa Timur Kota Surabaya yang digunakan sebagai responden dalam penelitian ini. Adapun metode yang digunakan dalam penelitian ini yaitu metode survey yang melakukan pengumpulan data dengan menggunakan instrumen kuisioner untuk mendapatkan respon dari responden yang menjadi sampel penelitian.

Intensitas adalah suatu keadaan tingkatan atau ukuran intensnya. Sedangkan yang dimaksud dengan moral ialah istilah atau ucapan seseorang (manusia) yang menyebut manusia lainnya dalam hal tindakan yang memiliki nilai yang positif. Sehingga, apabila diartikan secara bersamaan, intensitas moral ialah variabel atau konstruk yang terdiri atas karakteristik - karateristik yang merupakan perluasan dari berbagai isu yang berkaitan dengan isu moral utama atas suatu situasi, yang kemudian hal tersebut dapat mempengaruhi persepsi dan keyakinan seorang individu mengenai hal yang kemudian ia percayai (Husniati, 2017).

Pengukuran intensitas moral dalam penelitian ini akan menggunakan indikator - indikator seperti yang telah diakukan penelitian (Kreshastuti \& Prastiwi, 2014) yaitu nilai moral, masalah etika, probabilitas efek, besaran konsekuensi, konsensus sosial.

Komitmen profesional berhubungan dengan sifat yang dibentuk oleh individu terhadap profesi mereka masing-masing (Aranya et al., 1981). Komitmen ini meliputi kepercayaan, penerimaan, sasaran dan nilai terhadap profesi. Terdapat keinginan untuk bekerja atas nama profesi dan ada keinginan untuk bertahan didalam 
profesi yang dimaksud. Indikator yang digunakan dalam penelitian ini adalah indikator yang dikembangkan oleh (Setyadi, 2008). Indikator tersebut yaitu kecintaan dan komitmen terhadap profesi, kinerja tugas profesi pegawai, pengembangan karir profesi pegawai, pandangan mengenai profesi sebagai pegawai, tanggungjawab pegawai terhadap profesinya.

Dalam organisasi, anggota yang mengetahui atapun mengamati adanya tindakan wrongdoing atau kecurangan, terlebih lagi jika tindakan wrongdoing tersebut bersifat serius, maka ia akan lebih cenderung ingin melakukan tindakan whistleblowing (Miceli \& Near, 1985).

Variabel ini akan menggunakan indikator seperti yang telah dilakukan oleh (Sabang, 2013; Winardi, 2013). Pengukuran tersebut menggunakan model kuesioner dan manipulasi dalam bentuk kasus cerita, namun dimodifikasi sesuai dengan keadaan setempat. Kasus diceritakan dalam skenario yang realistis dan memungkinkan responden untuk menempatkan diri dalam posisi karakter yang digambarkan dalam skenario yaitu sebagai kasus yang digambarkan sebagai kasus kecurangan markup realisasi belanja yang umum terjadi di Indonesia dengan nilai materialitas kecurangan yang sebesar 9\%. Kemudian ditanyakan bagaimana penilaian responden apabila materialitas kecurangan pada kasus markup realisasi belanja diturunkan (menjadi 0,2\%).

Whistleblowing merupakan tindakan pengungkapan kecurangan baik ke internal maupun eksternal yang dilakukan oleh anggota organisasi. Whistleblowing dalam penelitian ini menggunakan indikator yang dilakukan oleh (Hasanah, 2017) yaitu niat, keinginan, rencana, usaha keras internal whistleblowing, usaha keras external whistleblowing.

Populasi penelitian adalah seluruh pegawai yang bekerja di Badan Pendapatan Daerah Jawa Timur Kota Surabaya. Teknik pengambilan sampel untuk penelitian ini yaitu menggunakan teknik purposive samplin dan dapat disebut sebagai judgment sampling (Sanusi, 2014). Adapun kriteria yang digunakan untuk memilih sampel dalam penelitian ini, yaitu pegawai yang berpengalaman masa kerja minimal 5 tahun di bidang perkejaan yang tetap, pegawai yang sudah berusia 30 tahun, pegawai dengan status sebagai Pegawai Negeri Sipil (PNS) maupun Pegawai Tidak Tetap (PTT), pegawai yang memiliki jabatan minimal golongan III (tiga) atau minimal telah menempuh pendidikan formal D4 atau setara dengan S1. Dengan beberapa kriteria yang telah ditetapkan maka sampel yang digunakan sebanyak 112 responden sebagaimana disajikan pada tabel berikut:

\section{Tabel 1. Seleksi sampel}

\begin{tabular}{lc}
\hline Keterangan & Jml \\
\hline Seluruh pegawai yang bekerja pada Badan Pendapatan Daerah Jawa Timur Kota Surabaya di & 164 \\
4 (empat) Unit Pelayanan Teknis (UPT) & 148 \\
Pegawai yang berpengalaman masa kerja minimal 5 tahun di bidang perkejaan yang tetap & 133 \\
Pegawai dengan usia minimal bekerja 30 tahun & 119 \\
Pegawai dengan status sebagai Pegawai Negeri Sipil (PNS) maupun Pegawai Tidak Tetap & 112 \\
(PTT) & \\
Pegawai yang memiliki jabatan minimal golongan III (tiga) atau minimal telah menempuh & 112 \\
\hline pendidikan formal D4 atau setara dengan S1 & \\
\hline Jumlah
\end{tabular}




\section{HASIL PENELITIAN}

Subyek yang dijadikan responden dalam penelitian ini adalah pegawai yang memiliki jabatan minimal golongan III (tiga) yang bekerja di Badan Pendapatan Daerah Jawa Timur Kota Surabaya, dengan pengalaman masa kerja minimal 5 tahun dibidang perkejaan yang tetap sebanyak 103 pegawai. Karakteristik responden yang diuraikan sebagai subjek penelitian yang meliputi jenis kelamin dan tingkat pendidikan terakhir sebagai berikut:

Tabel 2. Profil Responden

\begin{tabular}{ccc}
\hline Item & Jumlah & Prosentase \\
\hline Wanita & 31 & $30,1 \%$ \\
Lelaki & 72 & $69,9 \%$ \\
Jumlah & 103 & $100 \%$ \\
Diploma Empat (D4) & 14 & $13,6 \%$ \\
Strata Satu (S1) & 68 & $66,0 \%$ \\
Strata Dua (S2) & 21 & $20,4 \%$ \\
\hline Jumlah & 103 & $100 \%$ \\
\hline
\end{tabular}

Sumber: SPSS 16, 2020 (diolah oleh penulis)

Sebelum melakukan uji hipotesis, peneliti melakukan analisis statistik deskriptif terlebih dahulu. Analisis deskriptif berfungsi untuk menggambarkan atau mendeskripsikan penelitian pada objek dengan data yang telah dikumpulkan, tanpa bermaksud membuat kesimpulan untuk umum (Sugiyono, 2016). Tabel hasil statistik deskriptif yang telah berisi variabel penelitian, jumlah sampel, nilai minimum, nilai maksimum, mean dan standar devisiasi, yang ditsajikan pada tabel 1. Kemudian, untuk mengetahui hasil rata-rata tanggapan responden berdasarkan hasil analisis deskriptif perlu menggunakan interval class yang bertujuan untuk menghitung nilai atau skor jawaban yang diisi oleh responden. Kelas interval disajikan pada tabel 2 .

Berdasarkan tabel analisis deskriptif dapat dijelaskan bahwa intensitas moral (IM) memiliki nilai minimum sebesar 3 dan nilai maksimum sebesar 5 , serta rata-rata 4 dan standar devisiasi 0,41. Artinya, memiliki nilai terendah dari jawaban responden adalah 3 atau dinyatakan ragu ragu, serta nilai tertinggi dari jawaban responden adalah 5 atau dinyatakan sangat setuju, dan rata-rata jawaban responden bernilai 4. Dalam kelas interval, termasuk dalam kategori 3,40 $<\mathrm{IM} \leq 4,20$ yang menunjukkan responden memberi nilai "setuju" atas pernyataan tentang semua aspek dalam intensitas moral.

Tabel 3. Analisis Deskriptif

\begin{tabular}{llcccc}
\hline Variabel & N & Minimum & Maximum & Mean & Std. Deviation \\
\hline Intensitas Moral & 103 & 3 & 5 & 4 & 0,41 \\
Komitmen Profesional & 103 & 3 & 5 & 3,75 & 0,57 \\
Tingkat Keseriusan Kecurangan & 103 & 3 & 4 & 3,91 & 0,28 \\
Niat untuk whistleblowing (NW) & 103 & 3.4 & 5 & 4,43 & 0,34 \\
Valid N (listwise) & 103 & & & & \\
\hline
\end{tabular}

Sumber: SPSS 16, 2020 (diolah oleh penulis)

Interval kelas $=\frac{\text { Nilai Tertinggi }- \text { Nilai Terendah }}{\text { Jumlah kelas }}=\frac{5-1}{5}=0,8$ 
Tabel 4. Kelas Interval Analisis Deskriptif

\begin{tabular}{rcc}
\hline Nilai Interval & Kategori & Nilai \\
\hline $4,20<$ IM,KP,TKK,NW $\leq 5,00$ & Sangat Setuju & 5 \\
$3,40<$ IM,KP,TKK,NW $\leq 4,20$ & Setuju & 4 \\
$2,60<$ IM,KP,TKK,NW $\leq 3,40$ & Cukup Setuju & 3 \\
$1,80<$ IM,KP,TKK,NW $\leq 2,60$ & Tidak Setuju & 2 \\
$1,00<$ IM,KP,TKK,NW $\leq 1,80$ & Sangat Tidak Setuju & 1 \\
\hline
\end{tabular}

Sumber: Singarimbun, 2009

Komitmen profesional (KP) menghasilkan nilai minimum sebesar 3 dan nilai maksimum sebesar 5, serta rata-rata 3,75 dan standar devisiasi 0,57. Artinya, komitmen profesional (KP) memiliki nilai terendah dari jawaban responden adalah 3 atau dinyatakan ragu - ragu, serta nilai tertinggi dari jawaban responden adalah 5 atau dinyatakan sangat setuju, dan rata-rata jawaban responden bernilai 3,75 yang termasuk dalam kelas interval kategori $3,40<\mathrm{KP} \leq 4,20$ atau dinyatakan "setuju" atas pernyataan tentang semua aspek dalam komitmen profesional.

Tingkat keseriusan kecurangan (TKK) menghasilkan nilai minimum sebesar 3 dan nilai maksimum sebesar 4 , serta ratarata 3,91 dan standar deviasi 0,28. Artinya, tingkat keseriusan kecurangan (TKK) memiliki nilai terendah dari jawaban responden adalah 3 atau dinyatakan ragu ragu, serta nilai tertinggi dari jawaban responden adalah 4 atau dinyatakan setuju, dan rata-rata jawaban responden bernilai 3,91 yang termasuk dalam kelas interval kategori $3,40<$ TKK $\leq 4,20$ atau dinyatakan "setuju" atas pernyataan tentang semua aspek dalam tingkat keseriusan kecurangan.

Terakhir, niat untuk whistleblowing (NW) menghasilkan nilai minimum sebesar 3,4 dan nilai maksimum sebesar 5 , serta ratarata 4,44 dan standar devisiasi 0,34.
Artinya, niat untuk whistleblowing (NW) memiliki nilai terendah dari jawaban responden adalah 3,4 atau dinyatakan ragu - ragu, serta nilai tertinggi dari jawaban responden adalah 5 atau dinyatakan sangat setuju, dan rata-rata jawaban responden bernilai 4,44 yang termasuk dalam interval kelas kategori $4,20<\mathrm{NW} \leq 5,00$ dinyatakan "sangat setuju" atas pernyataan tentang semua aspek dalam niat untuk whistleblowing.

Pengujian hipotesis dalam penelitian ini dilakukan dengan membandingkan sigvalue dengan sig- $\alpha$ untuk masing - masing variabel (Ghozali, 2018). Penerapan uji hipotesis dalam penelitian ini didasarkan pada nilai Ha sebagai variabel independen yang berpengaruh terhadap variabel dependen Untuk menentukan Ha ditolak atau diterima, maka ditetapkan alpha (tingkat signifikansi) sebesar 5\% sehingga kriteria keputusannya yaitu jika nilai signifikansi $>0,05$ maka Ha ditolak, sedangkan jika nilai signifikansi $<0,05$ maka Ha diterima.

Berdasarkan hasil pengujian hipotesis pada tabel 2 diatas, menunjukkan bahwa variabel independen intensitas moral, komitmen profesional, dan tingkat keseriusan kecurangan terhadap variabel dependen yaitu niat untuk whistleblowing, sebagai berikut: 
Ratna Arizka Primasari, Fidiana

Whistleblowing berdasarkan Intensitas Moral, Komitmen Profesional, dan Tingkat Keseriusan Kecurangan

Tabel 5. Hasil Pengujian Hipotesis

\begin{tabular}{lcccc}
\hline \multicolumn{1}{c}{ Variabel Independen } & Koefisien Regresi & t output & Signifikansi & Keterangan \\
\hline Intensitas Moral & 0,510 & 4,733 & 0,00 & Berpengaruh \\
Komitmen Profesional & 0,140 & 1,988 & 0,50 & Berpengaruh \\
Tingkat Keseriusan Kecurangan & 0,463 & 5,839 & 0,00 & Berpengaruh \\
Konstanta $=-0,379$ & & & \\
Adjusted $\mathrm{R}^{2}=0,830$ & & & \\
F Hitung $=161,492$ & & & \\
\hline Sumber: SPSS 16, 2020 (diolah oleh penulis) & &
\end{tabular}

Hipotesis 1 adalah pengaruh intensitas moral terhadap niat untuk whistleblowing, dengan hasil signifikansi yaitu 0,000. Hal ini menunjukkan bahwa nilai signifikansi intensitas moral $<0,05$ dengan nilai $\beta$ sebesar 0,510 . Dengan nilai positif pada $\beta$ dapat disimpulkan bahwa Ha diterima, yang artinya intensitas moral berpengaruh positif terhadap niat untuk whistleblowing. Hipotesis 2 adalah pengaruh komitmen profesional terhadap niat untuk whistleblowing dengan menunjukkan hasil signifikansi yaitu 0,050. Hal ini menunjukkan bahwa nilai signifikansi < 0,05 dengan nilai $\beta$ sebesar 0,140 . Nilai positif pada $\beta$ dapat disimpulkan bahwa Ha diterima, yang menyatakan bahwa komitmen profesional berpengaruh positif terhadap niat untuk whistleblowing.

Hipotesis 3 adalah pengaruh tingkat keseriusan kecurangan terhadap niat untuk whistleblowing dengan hasil signifikansi yaitu 0,000 . Hal ini menunjukkan bahwa nilai signifikansi $<0,05$ dengan nilai $\beta$ sebesar 0,463 . Nilai positif pada $\beta$ dapat disimpulkan bahwa Ha diterima, yang manyatakan bahwa tingkat keseriusan kecurangan berpengaruh positif terhadap niat untuk whistleblowing.

Dan berdasarkan tabel 1 diketahui bahwa besarnya nilai koefisien determinasi intensitas moral, komitmen profesional, dan tingkat keseriusan kecurangan ditunjukan oleh nilai adjusted $\mathrm{R}^{2}$ yaitu sebesar 0,830 yang artinya variabel intensitas moral, komitmen profesional, dan tingkat keseriusan kecurangan memiliki kontribusi sebesar $83 \%$ terhadap niat untuk whistleblowing, dan sebagiannya lagi diterangkan oleh variabel lainnya yang tidak ditunjukkan dalam penelitian ini sebesar $17 \%$.

\section{PEMBAHASAN}

Pengaruh Intensitas Moral (IM) terhadap Niat untuk Whistleblowing (NW)

Hasil pengujian menunjukkan bahwa intensitas moral (IM) berpengaruh positif terhadap niat untuk whistleblowing (NW) pegawai yang bekerja di Badan Pendapatan Daerah Jawa Timur Kota Surabaya yang menyatakan bahwa semakin tinggi tingkat intensitas moral positif yang dimiliki artinya, pegawai akan mempertimbangkan matang - matang sebelum menilai bahkan menindak niat untuk whistleblowing yang dilakukan diri sendiri maupun dari rekanan kerja di wilayah BAPENDA Jawa Timur di Kota Surabaya.

Hasil ini mendukung theory of planned behavior dalam konsep persepsi kontrol perilaku. Individu akan berperilaku dan mengambil keputusan dipengaruhi oleh intensitas moral dengan menentukan tepat dan benarnya perilaku untuk melakukan yang kemudian akan mengambil keputusan, akan bergantung sekali pada tingkat intensitas moral dari individu tersebut (Zanaria, 2016). Saat seorang individu memiliki keyakinan bahwa mempertimbangkan risiko atau kerugian atas tindakannya dapat diterima di lingkungannya dan percaya bahwa tindakan yang dilakukan adalah hasil dari kontrol dirinya sendiri maka seorang individu tersebut akan memiliki niat untuk berperilaku (Jones, 1991). 
Hasil penelitian ini didukung oleh penelitian (Aditya Pandu Wicaksono, Dekar Urumsah, 2018; Gandamihardja, Gunawan, \& Maemunah, 2016; Hariyani \& Putra, 2018; Setiawati \& Sari, 2016) yang menemukan bahwa intensitas moral berpengaruh positif terhadap niat untuk whistleblowing. Hal ini menunjukkan bahwa intensitas moral merupakan sesuatu yang penting bagi setiap individu. Tingkat moralitas yang tinggi yang dimiliki oleh karyawan akan menjadi kontrol perilaku dalam memutuskan untuk melaporkan tindak kecurangan (Stikeleather, 2016), karena orang yang memiliki intensitas moral yang tinggi akan cenderung untuk melakukan tindakan yang dianggapnya benar maka tentunya akan cenderung melakukan hal-hal yang memiliki dampak yang baik untuk ke depannya, termasuk di dalamnya melakukan tindakan whistleblowing (Ahmad et al., 2014).

\section{Pengaruh Komitmen Profesional (KP) terhadap Niat untuk Whistleblowing (NW)}

Variabel komitmen profesional (KP) menyatakan hasil bahwa berpengaruh positif terhadap niat untuk whistleblowing (NW) pegawai yang bekerja di Badan Pendapatan Daerah Jawa Timur Kota Surabaya. Hasil ini menunjukan bahwa semakin tinggi tingkat komitmen profesional, maka niat untuk whistleblowing juga akan meningkat sehingga kecenderungan saling melaporkan tersebut akan terjadi.

Komitmen profesi dapat diartikan sebagai individu yang memiliki rasa cinta dan suka terhadap profesinya saat ini (Joneta, 2016). Seorang individu yang memiliki komitmen profesi berarti memiliki rasa tanggung jawab untuk melindungi profesinya sehingga jika mengetahui adanya pelanggaran atau tindakan menyimpang yang berada disekitar terhadap peraturan yang berlaku akan menimbulkan intensi untuk melaporkan perilaku kecurangan di lingkungan tersebut (Setiawati \& Sari, 2016).

Hasil penelitian ini didukung oleh penelitian (Aditya Pandu Wicaksono, Dekar Urumsah, 2018; Gandamihardja et al., 2016; Hariyani \& Putra, 2018; Joneta, 2016; Setiawati \& Sari, 2016) yang menyatakan bahwa komitmen profesional berpengaruh positif terhadap niat untuk whistleblowing. Individu yang memiliki profesionalisme atau rasa dedikasi yang tinggi terhadap profesinya dan seiring dengan standar etika dan profesional yang mencakup tanggungjawabnya dalam organisasi akan berdampak pada pengambilan keputusannya, yang akan selaras dengan kepentingan organisasi (Makowsky \& Wang, 2018; Waytz, Dungan, \& Young, 2013). Sehingga, guna melindungi profesinya seseorang akan lebih merasa bertanggungjawab jika terjadi pelanggaran terhadap peraturan yang berlaku hingga menimbulkan niat untuk melaporkan perilaku kecurangan di lingkungan kerja.

\section{Pengaruh Tingkat Keseriusan Kecurangan (TKK) terhadap Niat untuk Whistleblowing (NW)}

Hasil pengujian menunjukkan variabel tingkat keseriusan kecuranngan (TKK) berpengaruh positif terhadap niat untuk whistleblowing (NW) pegawai yang bekerja di Badan Pendapatan Daerah Jawa Timur Kota Surabaya. Hasil ini menunjukan bahwa semakin tinggi tingkat keseriusan kecurangan, maka niat untuk whistleblowing juga akan meningkat. Hal ini dikarenakan tingkat keseriusan kecurangan adalah ukuran seberapa besar keseriusan kecurangan yang dapat merugikan lembaga tersebut. Pegawai lainnya yang mengamati adanya dugaan pelanggaran akan lebih mungkin untuk melakukan whistleblowing jika pelanggaran tersebut serius (Waytz et al., 2013). Hasil penelitian ini sejalan dengan penelitian (Aida, Helmy, \& Setiawan, 2019; Hakim, Subroto, \& Andayani, 2017; 
Marliza, 2018; Wakerkwa et al., 2018) yang menemukan bahwa tingkat keseriusan kecurangan berpengaruh positif terhadap niat untuk whistleblowing.

Hal ini menunjukkan bahwa besar dan seriusnya tindakan kecurangan yang sangat berpotensi merugikan lembaga dan bahkan pada negara, maka tentunya hal ini yang semakin mendorong setiap karyawan untuk melakukan tindakan whistleblowing (Park \& Lewis, 2019) karena baginya, perusahaan akan terkena dampak berupa kerugian yang bersifat besar dan serius.

\section{KESIMPULAN DAN SARAN}

(1) Intensitas Moral (IM) berpengaruh positif terhadap Niat untuk Whistleblowing (NW). Hasil uji terhadap Pegawai Badan Pendapatan Daerah Jawa Timur membuktikan bahwa Intensitas moral (IM) berpengaruh positif terhadap niat untuk whistleblowing (NW). Ini berarti bahwa pegawai akan mempertimbangkan dengan baik sebelum menilai bahkan menindak niat untuk whistleblowing yang dilakukan diri sendiri (Choo, Grimm, Horváth, \& Nitta, 2019) maupun dari rekanan kerja di wilayah BAPENDA Jawa Timur di Kota Surabaya.

(2) Komitmen Profesional (KP) berpengaruh positif terhadap Niat untuk Whistleblowing (NW). Hasil uji terhadap Pegawai Badan Pendapatan Daerah Jawa Timur membuktikan bahwa semakin tinggi tingkat komitmen profesional, maka niat untuk whistleblowing juga akan meningkat (Brown et al., 2016; Hennequin, 2020). Hal ini dikarenakan jika individu memiliki komitmen profesional maka akan bertindak dan berperilaku sesuai kode etik serta aturan yang ada. Sehingga, saat penyalahgunaan terjadi, maka kecenderungan saling melaporkan tersebut akan terjadi.

(3) Tingkat Keseriusan Kecurangan (TKK) berpengaruh positif terhadap Niat untuk Whistleblowing (NW). Hasil uji terhadap Pegawai Badan Pendapatan
Daerah Jawa Timur membuktikan bahwa tingkat keseriusan kecurangan adalah ukuran seberapa besar keseriusan kecurangan yang dapat merugikan lembaga tersebut. Pegawai lainnya yang mengamati adanya dugaan pelanggaran akan lebih mungkin untuk melakukan whistleblowing jika pelanggaran tersebut serius (Alleyne, Haniffa, \& Hudaib, 2019).

\section{Keterbatasan dan Saran}

Penelitian ini mengandung keterbatasan terutama dalam pengumpulan data penelitian yang semula ditargetkan 112 sesuai jumlah sampel, namun hanya dapat terolah 103 saja karena ada beberapa kuesioner yang tidak diisi lengkap. Berdasarkan hasil penelitian yang berhasil mengonfirmasi semua hipotesis, penelitian ini penting memberi rekomendasi bagi BAPENDA Jawa Timur Kota Surabaya tentang pentingnya mempertahankan intensitas moral pegawai seperti besaran konsekuensi (magnitude of consequences), konsensus sosial (social consensus), probabilitas efek (probability of effect), nilai moral, dan masalah etika secara berkala, sehingga dapat meningkatkan dan mempengaruhi niat untuk whistleblowing. Kemudian diharapkan dapat meningkatkan komitmen profesional dengan cara menyelipkan pembacaan nilai-nilai organisasi dan profesi pada apel pagi guna untuk meningkatkan rasa peduli serta bertanggung jawab atas komitmen profesi yang dimiliki terhadap niat untuk whistleblowing. Dan juga diharapkan dapat meningkatkan pengawasan terhadap tingkat keseriusan kecurangan pada pegawai dengan melakukan audit dan evaluasi secara berkala setiap kegiatan atau pekerjaan yang telah dikerjakan;

(2) Bagi peneliti selanjutnya, diharapkan dapat menambahkan variabel lainnya seperti pengaruh sikap, persepsi kontrol perilaku, iklim etis dan lain - lain yang mempengaruhi niat untuk whistleblowing, sehingga dapat menambah temuan empiris terbaru dimasa yang akan datang dan dapat 
menjadi rujukan baru bagi BAPENDA Jawa Timur Kota Surabaya.

\section{REFERENSI}

ACFE. (2016). Survei Fraud Indonesia. Jakarta: ACFE Indonesia Chapter.

Aditya Pandu Wicaksono, Dekar Urumsah, B. E. S. (2018). Whistleblowing Intention: The Effects of Moral Intensity, Organizational and Professional Commitment. Jurnal Akuntansi, 22(3), 354. https://doi.org/10.24912/ja.v22i3.393

Ahmad, S. A., Yunos, R. M., Ahmad, R. A. R., \& Sanusi, Z. M. (2014). Whistleblowing Behaviour: The Influence of Ethical Climates Theory. Procedia - Social and Behavioral Sciences, 164, 445-450. https://doi.org/10.1016/j.sbspro.2014. 11.101

Aida, R., Helmy, H., \& Setiawan, M. A. (2019). Faktor-Faktor yang Mempengaruhi Minat Pegawai Negeri Sipil (PNS) untuk Melakukan Tindakan Whistleblowing. Jurnal Eksplorasi Akuntansi, 1(4), 16331649.

https://doi.org/10.24034/j25485024.y 2015.v19.i2.1769

Ajzen, I. (1991). The theory of planned behavior. Organizational Behavior and Human Decision Processes, 50(2), 179-211. https://doi.org/10.1016/07495978(91)90020-T

Alfian, N., Subhan, \& Rahayu, R. P. (2018). Penerapan Whistleblowing System dan Surprise Audit sebagai Strategi Anti Fraud dalam Industri Perbankan. Jurnal Akuntansi Muhammadiyah, 8(2). https://doi.org/10.1017/CBO9781107 415324.004

Alleyne, P., Haniffa, R., \& Hudaib, M. (2019). Does group cohesion moderate auditors' whistleblowing intentions? Journal of International
Accounting, Auditing and Taxation, 34, 69-90. https://doi.org/10.1016/j.intaccaudtax. 2019.02.004

Amrullah, M. M., \& Kaluge, D. (2019). Implementasi Theory of Planned Behavior dalam Mendeteksi WhistleBlowing Intentions di Sektor Publik. 21(1).

Brief, A. P., \& Motowidlo, S. J. (1986). Prosocial Organizational Behavior. Academy of Management Review, 11, 710-725.

Brown, J. O., Hays, J., \& Stuebs, M. T. (2016). Modeling Accountant Whistleblowing Intentions: Applying the Theory of Planned Behavior and the Fraud Triangle. Accounting and the Public Interest, 16(1), 28-56. https://doi.org/10.2308/apin-51675

Choo, L., Grimm, V., Horváth, G., \& Nitta, K. (2019). Whistleblowing and diffusion of responsibility: An experiment. European Economic Review, 119, 287-301. https://doi.org/10.1016/j.euroecorev.2 019.07.010

Cressey, D. R. (1986). Why Managers Commit Fraud. Australian \& New Zealand Journal of Criminology, 19(4), 195-209.

Farooqi, S., Abid, G., \& Ahmed, A. (2017). How bad it is to be good: Impact of organizational ethical culture on whistleblowing (the ethical partners). Arab Economic and Business Journal, 12(2), 69-80. https://doi.org/10.1016/j.aebj.2017.06 .001

Gandamihardja, V. K., Gunawan, H., \& Maemunah, M. (2016). Pengaruh Komitmen Profesional dan Intensitas Moral terhadap Intensi Melakukan Whistleblowing ( Studi Auditor Internal yang Bekerja di BUMN ). Prosiding Akuntansi, 2(1), 271-278.

Ghozali, I. (2018). Aplikasi Analisis Multivariate dengan Program SPSS 25 (Edisi 9). Semarang: Badan 
Penerbit Universitas Diponegoro.

Hakim, T. I. R., Subroto, B., \& Andayani, W. (2017). Faktor Situsional dan Demografis sebagai Prediktor Niat Individu untuk Melakukan Whistleblowing. Jurnal Ilmiah Administrasi Publik (JIAP), 3(2), 124-133.

Hariyani, E., \& Putra, A. A. (2018). Pengaruh Komitmen Profesional, Lingkungan Etika, Intensitas Moral, Personal Cost Terhadap Intensi untuk Melakukan Whistleblowing Internal (Studi Empiris pada OPD Kabupaten Bengkalis). Jurnal Akuntansi, Keuangan Dan Bisnis, 11(2), 17-26.

Hartono, T., \& Cahaya, F. R. (2017). Whistleblowing Intention Sebagai Alat Antikorupsi Dalam Institusi Kepolisian. Akuisisi: Jurnal Akuntansi, 13(2), 45-61. https://doi.org/https://doi.org/10.2412 7/akuisisi.v13i2.156.g134

Hennequin, E. (2020). What motivates internal whistleblowing? A typology adapted to the French context. European Management Journal. https://doi.org/10.1016/j.emj.2020.03. 005

Iskandar, A., \& Saragih, R. (2018). Pengaruh Sikap ke Arah Perilaku, Norma Subjektif, dan Persepsi Kontrol atas Perilaku Terhadap Niat dan Perilaku Whistleblowing CPNS. Jurnal Tata Kelola \& Akuntabilitas Keuangan Negara, 4(1), 63. https://doi.org/10.28986/jtaken.v4i1.1 42

Jeon, S. H. (2017). Where to report wrongdoings? Exploring the determinants of internal versus external whistleblowing. International Review of Public Administration, 22(2), 153-171. https://doi.org/10.1080/12294659.201 7.1315235

Joneta, C. (2016). Pengaruh Komitmen Profesional dan Pertimbangan Etis terhadap Intensi Melakukan
Whistleblowing: Locus of Control Sebagai Variabel Moderasi. JOM Fekon, 3(1).

KKNG. (2008). Pedoman Sistem Pelaporan Pelanggaran atau Whistleblowing System. Bandung: Penerbit Remaja Rosdakarya.

Makowsky, M. D., \& Wang, S. (2018). Embezzlement, whistleblowing, and organizational architecture: An experimental investigation. Journal of Economic Behavior \& Organization, 147, 58-75. https://doi.org/10.1016/j.jebo.2017.12 .024

Marliza, R. (2018). Pengaruh Personal Cost of Reporting, Komitmen Organisasi, dan Tingkat Keseriusan Kecurangan terhadap Niat Melakukan Whistleblowing. Jurnal Akuntansi, $6(1)$.

Mohd Noor, N. R. A., \& Mansor, N. (2019). Exploring the Adaptation of Artificial Intelligence in Whistleblowing Practice of the Internal Auditors in Malaysia. Procedia Computer Science, 163, 434-439.

https://doi.org/10.1016/j.procs.2019.1 2.126

Near, J. P., \& Miceli, M. P. (2016). After the wrongdoing: What managers should know about whistleblowing. Business Horizons, 59(1), 105-114. https://doi.org/10.1016/j.bushor.2015. 09.007

Nisar, T. M., Prabhakar, G., \& Torchia, M. (2019). Whistleblowing. Organizational Dynamics, 48(1), 4449.

https://doi.org/10.1016/j.orgdyn.2018 .03 .003

Nur, S. W., \& Hamid, N. A. (2018). Pengaruh Profesionalisme dan Intensitas Moral Auditor Terhadap Intensi Melakukan Whistleblowing Pada Kantor Akuntan Publik Makassar. Assets, 8(2), 115-124.

Park, H., \& Lewis, D. (2019). The 
motivations of external whistleblowers and their impact on the intention to blow the whistle again. Business Ethics: A European Review, 28(3), 379-390. https://doi.org/10.1111/beer.12224

Sanusi, A. (2014). Metodologi Penelitian Bisnis (Cetakan Ke). Jakarta: Salemba Empat.

Saputra, A., Utami, I., \& Kristianti, I. (2018). Akuntabilitas Dan Transparansi Pelaporan Keuangan Pemerintah Daerah Serta Potensi Whistleblowing Atas Penyalahgunaan Dana. Jurnal Ilmiah Wahana Akuntansi, 13(1), 13-28. https://doi.org/https://doi.org/10.2100 9/wahana-akuntansi/13.1.02

Schultz, D., \& Harutyunyan, K. (2015). Combating corruption: The development of whistleblowing laws in the United States, Europe, and Armenia. International Comparative Jurisprudence, 1(2), 87-97. https://doi.org/10.1016/j.icj.2015.12.0 05

Setiawati, L. P., \& Sari, M. M. R. (2016). Profesionalisme, Komitmen Organisasi, Intensitas Moral Dan Tindakan Akuntan Melakukan Whistleblowing. E-Jurnal Akuntansi Universitas Udayana, 17(1), 257282.

Shawver, T. J., \& Shawver, T. A. (2018). The Impact of Moral Reasoning on Whistleblowing Intentions. Research on Professional Responsibility and Ethics in Accounting, 21, 153-168. https://doi.org/10.1108/S1574076520180000021005

Singarimbun, M. (2009). Metode Penelitian Survei. Jakarta: LP3ES.
Stikeleather, B. R. (2016). When do employers benefit from offering workers a financial reward for reporting internal misconduct? Accounting, Organizations and Society, 52, 1-14. https://doi.org/10.1016/j.aos.2016.06. 001

Sugiyono. (2016). Metode Penelitian dan Pengembangan $R \& D$ (Edisi Ke-2). Bandung: ALFABETA, CV.

Valentine, S., \& Godkin, L. (2019). Moral intensity, ethical decision making, and whistleblowing intention. Journal of Business Research, 98, 277-288. https://doi.org/10.1016/j.jbusres.2019 .01 .009

Wakerkwa, R., Falah, S., \& Safkaur, O. (2018). Faktor-Faktor yang Mempengaruhi Minat Aparatur Sipil Negara (ASN) untuk Melakukan Tindakan Whistle-Blowing Pada PEMDA Propinsi Papua. Jurnal Akuntansi, Audit \& Aset, 1(1), 42-57. https://doi.org/https://doi.org/10.3336 9/j.akuntansi.9.1.1-16

Waytz, A., Dungan, J., \& Young, L. (2013). The whistleblower's dilemma and the fairness-loyalty tradeoff. Journal of Experimental Social Psychology, 49(6), 1027-1033. https://doi.org/10.1016/j.jesp.2013.07 .002

Zanaria, Y. (2016). Pengaruh Profesonalisme Audit, Intensitas Moral untuk Melakukan Tindakan Whistleblowing (Studi pada KAP di Indonesia). Akuisisi: Jurnal Akuntansi, 12(1). https://doi.org/https://doi.org/10.2412 7/akuisisi.v12i1.95.g70 